УДК 614.841:536.46

\title{
ЗАКОНОМІРНОСТІ ВПЛИВУ ТЕХНОЛОГІЧНИХ ПАРАМЕТРІВ I ЗОВНІШНІХ ЧИННИКІВ НА ТЕМПЕРАТУРУ ЗАЙМАННЯ ТА ЧАС ЗГОРЯННЯ ЧАСТИНОК МАГНІЮ ТА АЛЮМІНІЮ В ПРОДУКТАХ РОЗКЛАДАННЯ ОКСИДІВ МЕТАЛІВ
}

https://doi.org/10.33269/nvcz.2021.2.111-121

\begin{abstract}
Кириченко Є. П., ORCID ID 0000-0001-7638-0722
Гвоздь В. M., ORCID iD 0000-0003-2277-7972

Ващенко В. M.,ORCID iD 0000-0003-0722-9353

Кириченко О. В.,ORCID ID 0000-0002-0240-1807

Дядюшенко О. O. , ,ORCID iD 0000-0003-0797-2251

Мельник В. П., ORCID ID 0000-0002-2354-9106

*E-mail : diadiushenko_oleksandr@chipb.org.in

Черкаський інститут пожежної безпеки імені Героїв Чорнобиля Національного університету цивільного захисту України
\end{abstract}

ІНФОРМАЦІЯ ПРО СТАТТЮ

Надійшла до редакції: 30.11.2021

Пройшла рецензування: 06.12.2021

КЛЮчОВІ СЛОВА:

піротехнічні металовмісні суміші,

пожежна безпека, процеси

займання та горіння частинок

металу.

Постановка проблеми. Нині піротехнічні суміші металевого пального (магнію, алюмінію та інших) 3 оксидами металів ( $\mathrm{CuO}, \mathrm{Cu}_{2} \mathrm{O}, \mathrm{Sb}_{2} \mathrm{O}_{3}, \mathrm{NiO}$ тощо) мають широке застосування у різноманітних галузях господарської діяльності та військово-промислового комплексу (спалахувальні суміші для сигнальних, освітлювальних і трасувальних засобів, піротехнічні випроби ІЧ-техніки, елементи ракетно-комічної техніки тощо) [1-7]. За умов вимушеного зовнішнього нагріву (наприклад, під час пожеж $\mathrm{y}$ будівлях та приміщеннях складського господарства, де зберігаються вироби, що оснащені зарядами 3 наведеними вище сумішами, за умов логістичного перенаправлення під час інтенсивного конвективного нагріву їх поверхонь, або за інтенсивним тепловим впливом на металеві корпуси виробів у разі польоту та пострілу) можливі спалахи піротехнічних сумішей зі стрімким прискоренням подальшого процесу їх спалахування та згоряння, знищенням виробів 3 утворенням високотемпературних продуктів горіння, котрі поширюються зі значними швидкостями у різні боки, що $\epsilon$ пожежобезпечними для навколишніх об'єктів інфраструктури (навколишніх споруд, паливно-мастильних матеріалів, пускових установок 3 обслуговуючим персоналом тощо) [8-15].

Отже, для попередження можливих пожежовибухонебезпечних руйнувань виробів у вказаних умовах необхідно насамперед володіти інформацією про закономірності процесу спалахування та горіння частинок металевого пального у газоподібних продуктах термічного розкладання окиснювачів, який передує процесу спалахування суміші.

Аналіз останніх досліджень і публікацій. На сьогодні достатньо повно проведено дослідження 3 визначення температури займання та часу горіння частинок металів ( $\mathrm{Mg}, \mathrm{Al}$, алюмінієвомагнісвих сплавів, Ti, Zr та інших) у 
газоподібних продуктах розкладання нітратовмісних окиснювачів (кисню, сумішах кисню 3 азотом, повітрі тощо) [16-24]. Було встановлено вплив природи окиснювача та металевого пального $[16 ; 18 ; 21 ; 23]$, а також дисперсності компонентів та зовнішніх умов (підвищених температур нагріву та зовнішніх тисків, складу навколишнього середовища) $[17 ; 19 ; 20 ; 22-24]$ на вказані характеристики займання та горіння частинок металевого пального.

Аналогічних досліджень для сумішей 3 порошків металевого пального та оксидів металів немає.

Методи досліджень. У науковій публікації були використані сучасні методи фізико-хімічного аналізу (кінозйомки та мікрокінозйомки, рентгеноструйного аналізу, безконтактні і контактні методи виміру температури), методи нелінійної теплопровідності та термостійкості, а також математичного й експериментальностатистичного моделювання. Розрахунки за моделями проведені у режимі реального часу та діалогу на засобах комп'ютерної техніки, що задовольняють сучасні вимоги щодо використання спеціального програмного забезпечення.

Мета статті. Метою цієї роботи $\epsilon$ встановлення закономірностей впливу технологічних параметрів і зовнішніх умов на температуру займання й час згоряння частинок магнію та алюмінію у газоподібних продуктах розкладання оксидів металів в умовах зовнішніх термічних дій.

Виклад основного матеріалу. Усі дослідження проводились на порошках металевого пального та оксидів металів, що випускаються піротехнічною промисловістю $[2 ; 4 ; 6]$. Для визначення температури займання $T_{3}$ та часу горіння $\tau_{2}$ частинок металу у продуктах розкладання окиснювачів використовувалось стандартне піротехнічне обладнання, що моделює вплив підвищених температур нагріву (до $1900 \ldots 2100$ К) та зовнішніх тисків (до $10^{7} \ldots 3 \cdot 10^{7}$ Па) навколишнього середовища [4; 6]. Водночас відносна похибка вимірювання параметрів $T_{3}$ та $\tau_{2}$ не перевищувала $7 . . .9 \%$.

У результаті проведених досліджень було встановлено, що за температур, властивих конденсованій фазі піротехнічних сумішей в умовах їх загоряння та розвитку горіння, основним активним газоподібним продуктом термічного розкладання сумішей металів $\epsilon$ $\mathrm{O}_{2}$. Отже, нижче розглядаються результати досліджень процесів займання та горіння частинок магнію та алюмінію у разі підвищених температур нагріву й зовнішніх тисків у вказаних газоподібних продуктах, зокрема повітрі, основою яких є суміш газів $\mathrm{O}_{2}+\mathrm{N}_{2}$.

Температура займання частинок магнію та алюмінію у газоподібних продуктах термічного розкладання окиснювача. Результати досліджень, що підтверджені експериментально, 3 визначення закономірностей впливу на температуру займання частинок металів ключових параметрів, таких як їх розмір, відносний масовий вміст кисню у потоці газоподібних продуктів розкладання окиснювача, а також тиск навколишнього середовища, що описують здатність їх до прискорення процесу спалахування й розвитку горіння в умовах збільшених температур нагріву і зовнішнього тиску, наведено на рис. 1, 2. 3 огляду на аналіз одержаних результатів з'ясовано, що у разі збільшення середнього розміру частинок порошку металу dм від 34 мкм до 310 мкм для діапазонів зміни відносної масової концентрації $\mathrm{O}_{2} \mathrm{C}_{\mathrm{O} 2}=0,2 \ldots 0,8$ та зовнішнього тиску $P=10^{5} \ldots 3 \cdot 10^{7}$ Па температура займання частинок $T_{3}$ зменшується у $1,3 \ldots 1,8$ раза. Водночас збільшення від 0,2 до 0,8 призводить до зниження $T_{3}$ у $1,3 \ldots 1,5$ раза, а підвищення $P$ від $10^{5}$ Па до $3 \cdot 10^{7}$ Па призводить до зменшення $T_{3}$ у $1,4 \ldots 1,7$ раза. 


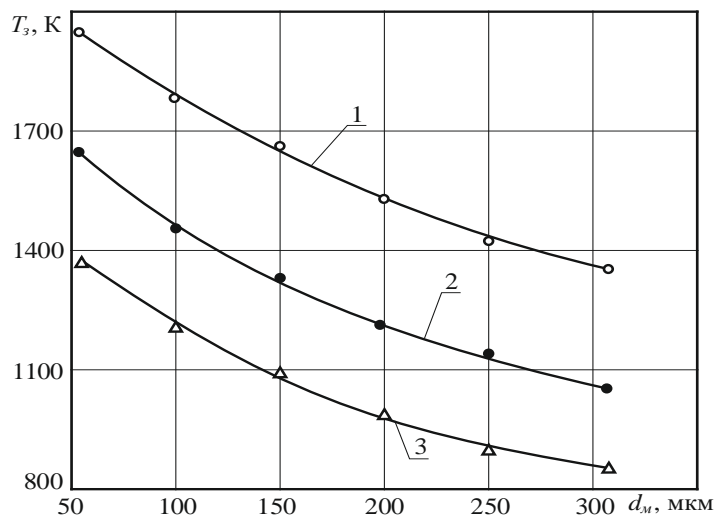

a)

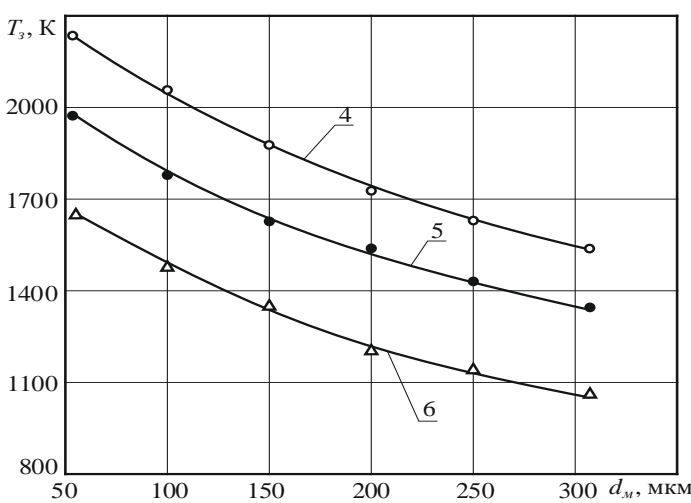

б)

Рисунок 1 - Вплив відносної концентрації кисню: а) $P=10^{5}$ Па та зовнішнього тиску б) $\mathrm{C}_{02}=0,4$ на залежність температури займання частинки магнію у продуктах розкладання окиснювача від ії розміру: $1-\mathrm{C}_{\mathrm{O} 2}=0,1 ; 2-\mathrm{C}_{\mathrm{O} 2}=0,4 ; 3-\mathrm{C}_{\mathrm{O} 2}=0,8 ; 4-P=3 \cdot 10^{7}$ Па; $5-P=10^{6}$ Па; $6-P=10^{5}$ Па; $\circ, \bullet, \Delta$ - експериментальні дані

Джерело: розроблено (узагальнено авторами)

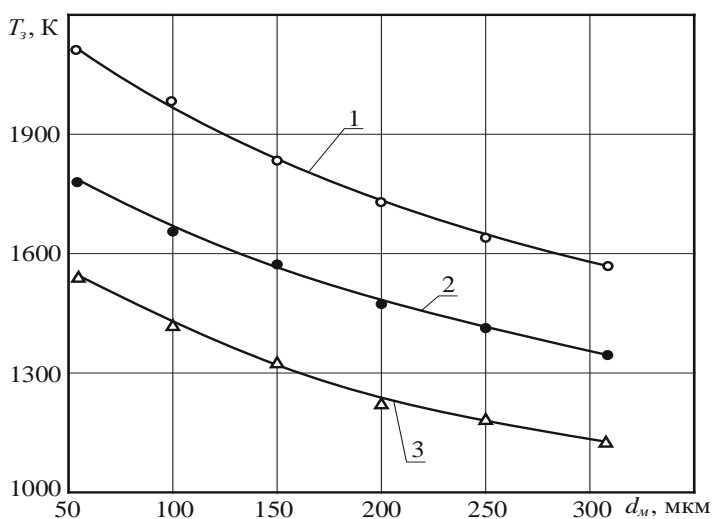

a)

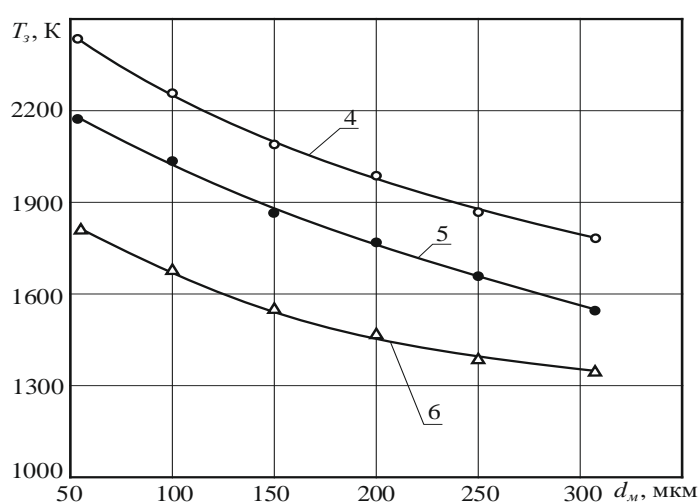

б)

Рисунок 2 - Вплив відносної концентрації кисню: а) $P=10^{5}$ Па та зовнішнього тиску б) $\mathrm{C}_{\mathrm{O} 2}=0,4$ на залежність температури займання частинки алюмінію у продуктах розкладання окиснювача від іiі po3міру: $1-\mathrm{C}_{\mathrm{O} 2}=0,1 ; 2-\mathrm{C}_{\mathrm{O} 2}=0,4 ; 3-\mathrm{C}_{\mathrm{O} 2}=0,8 ; 4-P=3 \cdot 10^{7} \Pi \mathrm{a} ; 5-P=10^{6} \Pi \mathrm{a} ; 6-P=10^{5}$ Па; ○, •, $\Delta$ - експериментальні дані

Джерело: розроблено (узагальнено авторами)

Час згоряння частинок магнію та алюмінію $у$ газоподібних продуктах термічного розкладання окиснювача. Результати проведених експериментальних досліджень 3 визначення закономірностей впливу на час згоряння $\left(\tau_{2}, \mathrm{c}\right)$ частинок металів у потоці газоподібних продуктів розкладання окиснювача їх розміру $\left(d_{M}\right.$, мкм), відносної масової концентрації кисню $\left(\mathrm{C}_{\mathrm{O} 2}\right)$ та зовнішнього тиску $(P$, Па) наведено на рис. 3,4 . 


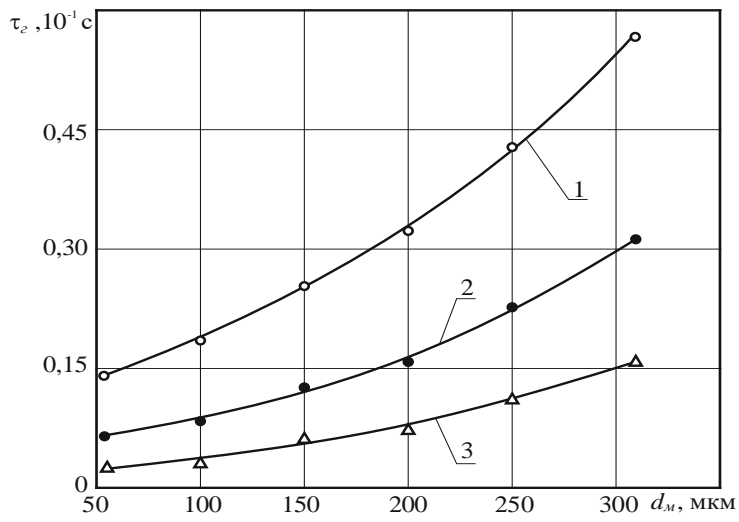

a)

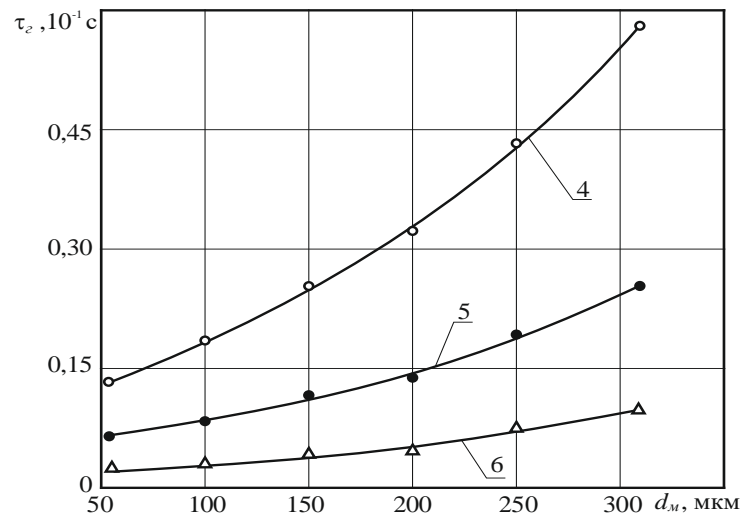

б)

Рисунок 3 - Вплив відносної концентрації кисню: а) $P=10^{5}$ Па та зовнішнього тиску б) $\mathrm{C}_{\mathrm{O} 2}=0,4$ на залежність часу згоряння частинки магнію у продуктах розкладання окиснювача від іiі розміру: $1-\mathrm{C}_{02}$ $=0,1 ; 2-\mathrm{C}_{\mathrm{O} 2}=0,4 ; 3-\mathrm{C}_{\mathrm{O} 2}=0,8 ; 4-P=10^{5} \Pi \mathrm{a} ; 5-P=10^{6}$ Па; $6-P=3 \cdot 10^{7}$ Па; $\circ, \bullet, \Delta$ - експериментальні дані

Джерело: розроблено (узагальнено авторами)

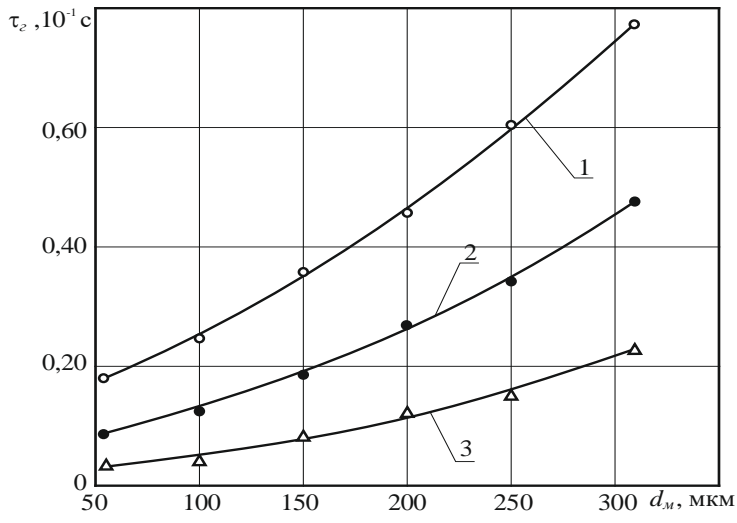

a)

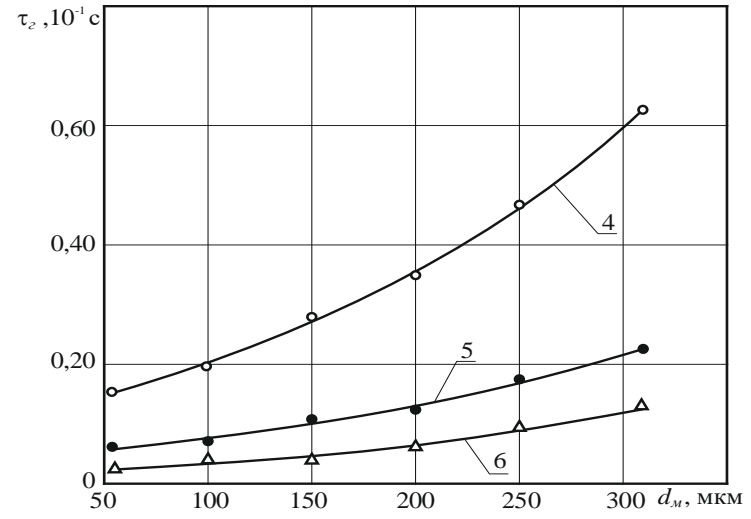

б)

Рисунок 4 - Вплив відносної концентрації кисню: а) $P=10^{5}$ Па та зовнішнього тиску б) $\mathrm{C}_{\mathrm{O} 2}=0,4$ ) на залежність часу згоряння частинки алюмінію у продуктах розкладання окиснювача від ії розміру: $1-\mathrm{C}_{\mathrm{O} 2}=0,1 ; 2-\mathrm{C}_{\mathrm{O} 2}=0,4 ; 3-\mathrm{C}_{\mathrm{O} 2}=0,8 ; 4-P=10^{5}$ Па; $5-P=10^{6}$ Па; $6-P=3 \cdot 10^{7}$ Па; $\circ, \bullet, \Delta$ - експериментальні дані

Згідно з аналізом отриманих даних, наведених на рис. 3, 4, показано, що зміна зазначених параметрів достатньо вагомо впливає на характер поведінки часу горіння частинок металевого пального: збільшення $d_{M}$ призводить до помітного зростання $\tau_{2}$ (у $2 \ldots 4$ рази), а збільшення , $V$ та $P$ - до зменшення $\tau_{2}$ у $2 \ldots 2,5$ раза (для $\mathrm{C}_{\mathrm{O} 2}$ ), у $1,8 \ldots 3,7$ раза (для $V$ ) та у $1,6 \ldots 3,5$ раза (для $P)$.

\section{Експериментально-статистичні}

моделі для визначення діапазонів зміни температури займання та часу горіння частинок магнію та алюмінію $y$ газоподібних продуктах розкладання оксидів металів. Для практичного
Джерело: розроблено (узагальнено авторами)

використання отриманих вище результатів щодо займання та горіння розглядуваних сумішей необхідно створити базу даних, зручну для оцінок пожежонебезпечних властивостей піротехнічних виробів на їх основі в умовах зовнішніх термічних дій, основними параметрами яких $\epsilon$ підвищені температури нагріву та зовнішній тиск. Водночас пожежонебезпечні режими горіння сумішей характеризуються передчасним займанням та вибухонебезпечним згорянням частинок порошків магнію та алюмінію у продуктах розкладання оксидів металів, що призводить до вибухового нагрівання зарядів сумішей та викиду у різні боки 
продуктів згоряння із залишками оболонок та окремих частинок зарядів, що продовжують горіти. 3 метою одержання відповідного датасету необхідно систематизувати дані щодо займання та горіння сумішей, які розглядаються (i пріоритетно за температурою займання та часом спалахування частинок металевого пального) у вигляді нескладних експериментально-статистичних моделей, прикладних для практичних оцінок.

Для вирішення поставленого завдання були використані поширені методи експериментально-статистичного моделювання $[2 ; 5 ; 6]$ та стандартне програмне забезпечення у вигляді пакетів прикладних програм за сучасними чисельними методами $[4 ; 6]$, які дають змогу в діалоговому режимі за отриманими моделями розраховувати діапазони зміни температури займання та часу згоряння частинок магнію та алюмінію, швидкості горіння сумішей, які розглядаються, що характеризують їх потенціал до прискорення процесу горіння в умовах підвищених температур нагріву та зовнішніх тисків.

За отриманими даними були розроблені нові експериментально-статистичні моделі (відносна похибка $5 \ldots 7$ \%):

$$
\begin{gathered}
T_{3}\left(d_{M}, C_{O_{2}}, P\right)=A_{0}+A_{1} \cdot C_{O_{2}}+A_{2} \cdot C_{O_{2}}^{2}+A_{3} \cdot d_{M}+A_{4} \cdot d_{M}^{2}+A_{5} \cdot P+A_{6} \cdot P^{2}+A_{7} \cdot C_{O_{2}} \cdot d_{M} \\
\tau_{2}\left(d_{M}, C_{O_{2}}, P\right)=B_{0}+B_{1} \cdot C_{O_{2}}+B_{2} \cdot C_{O_{2}}^{2}+B_{3} \cdot d_{M}+B_{4} \cdot d_{M}^{2}+B_{5} \cdot P+B_{6} \cdot P^{2}+B_{7} \cdot C_{O_{2}} \cdot d_{M}
\end{gathered}
$$

де $A_{i} B_{i}$, (i= $\overline{0.7}$ - емпіричні коефіцієнти, що залежать від природи металевого пального та окиснювача (табл. 1, 2). Діапазони зміни змінних у формулах (1), (2): $C_{O_{2}}=0,1 \ldots 0,8 ; P=10^{5} \ldots 3 \cdot 10^{7}$ Па; $d_{м}=35,8 \ldots 385$ мкм (для $\left.\mathrm{Mg}\right) ; d_{м}=54 \ldots 310$ мкм (для $A_{1}$ ).

Таблиця 1 - Значення коефіцієнтів у формулах (1), (2) для сумішей $\mathrm{Mg}+$ оксиди металів

\begin{tabular}{|c|c|c|c|c|c|c|c|}
\hline$A_{0}$ & $A_{1}$ & $A_{2}$ & $A_{3}$ & $A_{4}$ & $A_{5}$ & $A_{6}$ & $A_{7}$ \\
\hline 1473 & $-113,4$ & $-17,2$ & $-0,07$ & $-0,93 \cdot 10^{-6}$ & $-0,97 \cdot 10^{-4}$ & $-0,38 \cdot 10^{-11}$ & $-0,85 \cdot 10^{-3}$ \\
\hline$B_{0}$ & $B_{1}$ & $B_{2}$ & $B_{3}$ & $B_{4}$ & $B_{5}$ & $B_{6}$ & $B_{7}$ \\
\hline 0,78 & 0,01 & 0,025 & $1,67 \cdot 10^{-2}$ & $-1,28$ & $-0,65$ & 0,15 & $0,31 \cdot 10^{-3}$
\end{tabular}

Таблиия 2 - Значення коефіцієнтів у формулах (1), (2) для сумішей $A_{1}+$ оксиди металів

\begin{tabular}{|c|c|c|c|c|c|c|c|}
\hline$A_{0}$ & $A_{1}$ & $A_{2}$ & $A_{3}$ & $A_{4}$ & $A_{5}$ & $A_{6}$ & $A_{7}$ \\
\hline 1534 & $-87,3$ & $-15,4$ & $-0,05$ & $-0,65 \cdot 10^{-6}$ & $-0,71 \cdot 10^{-4}$ & $-0,23 \cdot 10^{-11}$ & $-0,63 \cdot 10^{-3}$ \\
\hline$B_{0}$ & $B_{1}$ & $B_{2}$ & $B_{3}$ & $B_{4}$ & $B_{5}$ & $B_{6}$ & $B_{7}$ \\
\hline & & & & & & & \\
\hline 0,87 & 0,18 & 0,038 & $1,81 \cdot 10^{-2}$ & $-1,62$ & $-0,84$ & 0,27 & $0,43 \cdot 10^{-3}$
\end{tabular}

Джерело: розроблено (узагальнено авторами) 


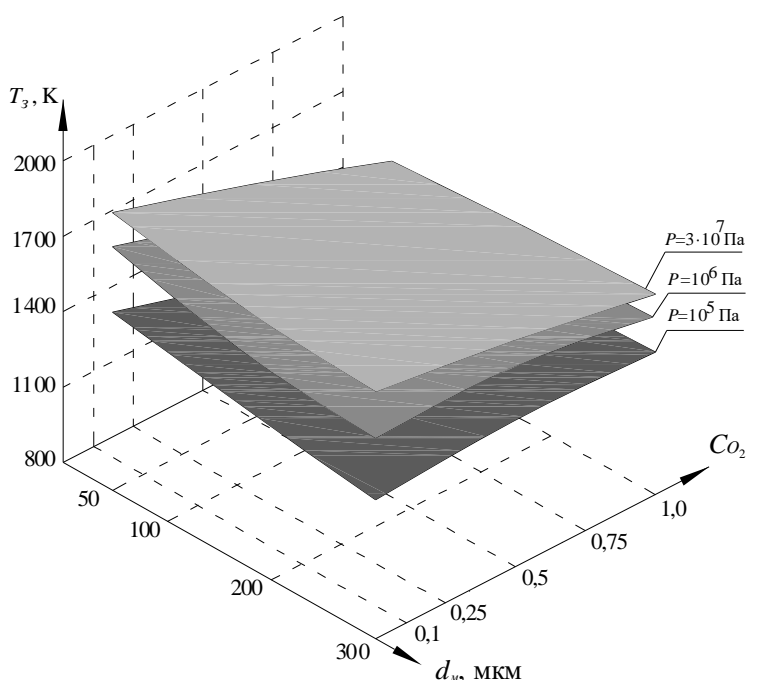

a)

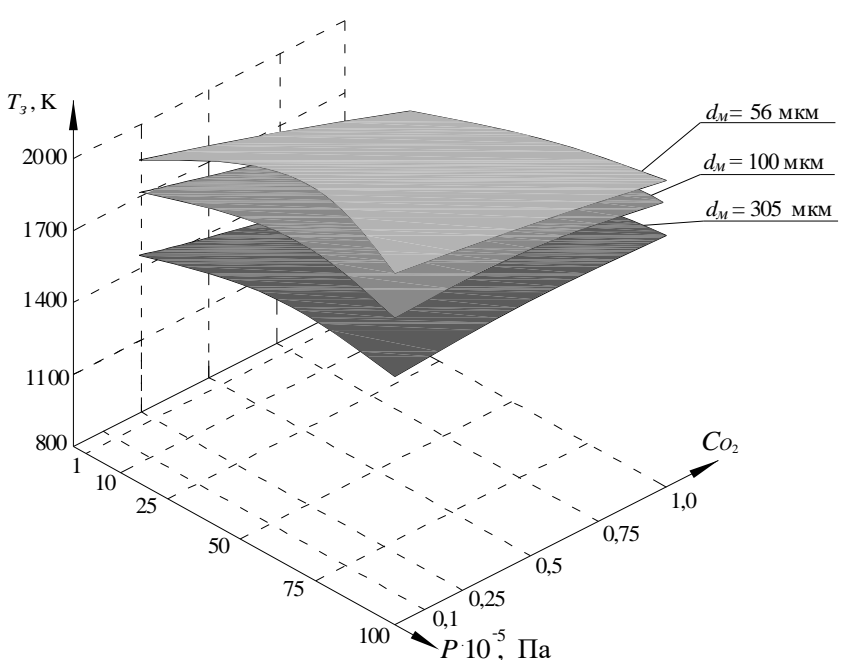

б)

Рисунок 5 - Тримірне зображення залежностей температури займання частинки магнію у продуктах розкладання окиснювача: а) від $\mathrm{C}_{\mathrm{O} 2}$ та $d_{s}$; б) від $\mathrm{C}_{\mathrm{O} 2 \text { та } P}$

Джерело: розроблено (узагальнено авторами)

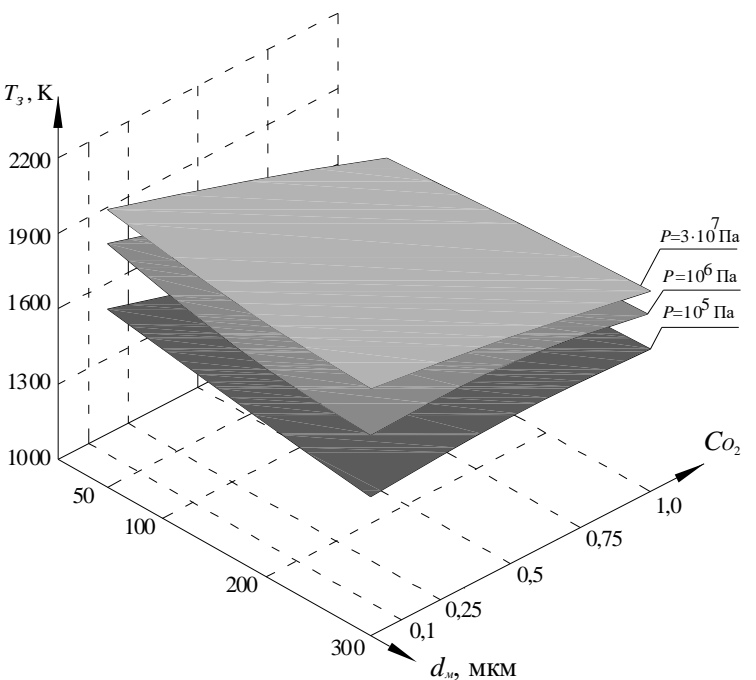

a)

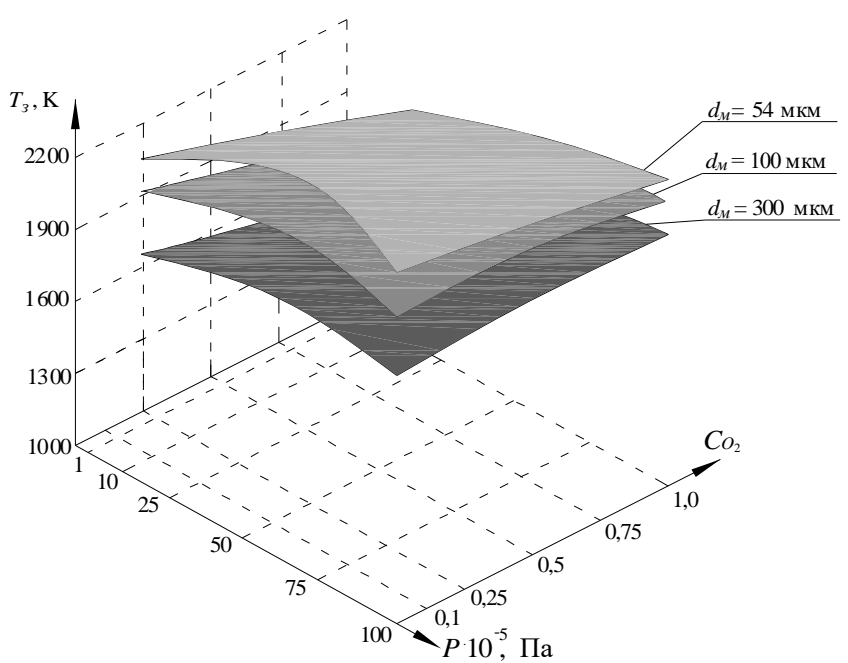

б)

Рисунок 6 - Тримірне зображення залежностей температури займання частинки алюмінію у продуктах розкладання окиснювача: а) від $\mathrm{C}_{02}$ та $d_{M}$; б) від $\mathrm{C}_{02}$ та $P$ 


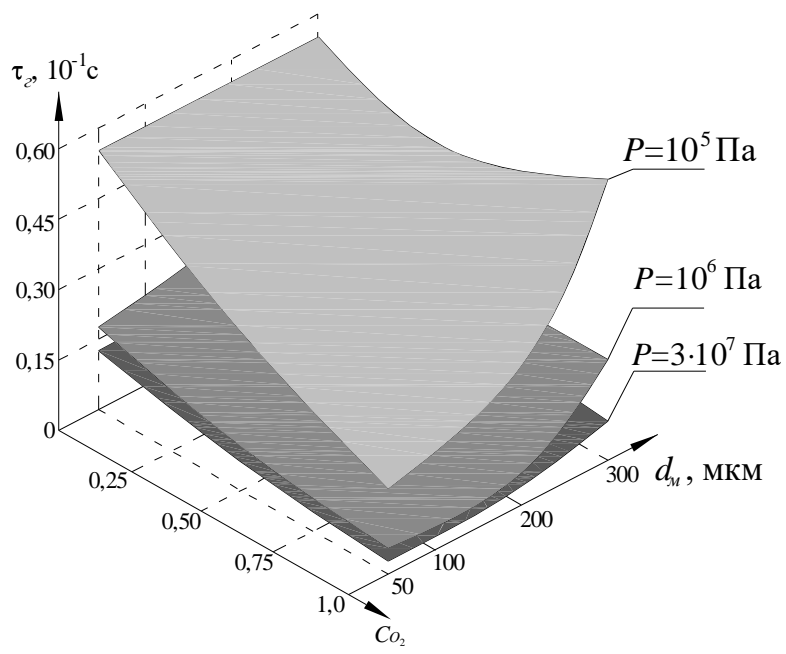

a)

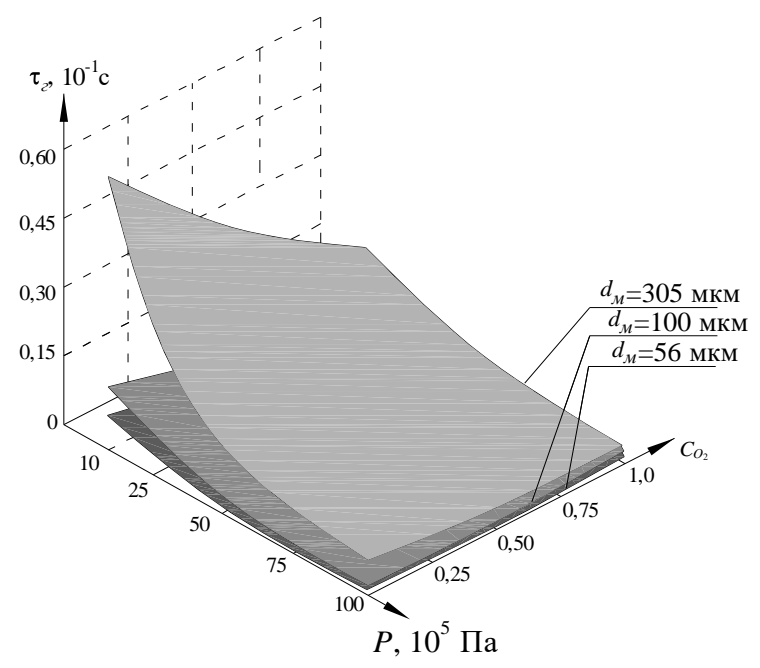

б)

Рисунок 7 - Тривимірне зображення залежностей часу згоряння частинки магнію у продуктах розкладання окиснювача: а) від $d_{m}$ та $\mathrm{C}_{\mathrm{O} 2}$; б) від $\mathrm{C}_{\mathrm{O} 2}$ та $P$

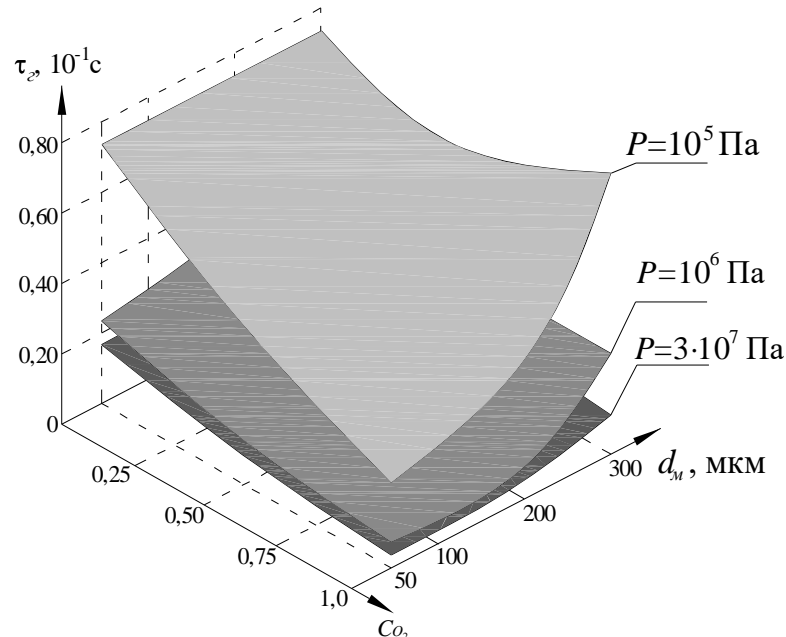

a)

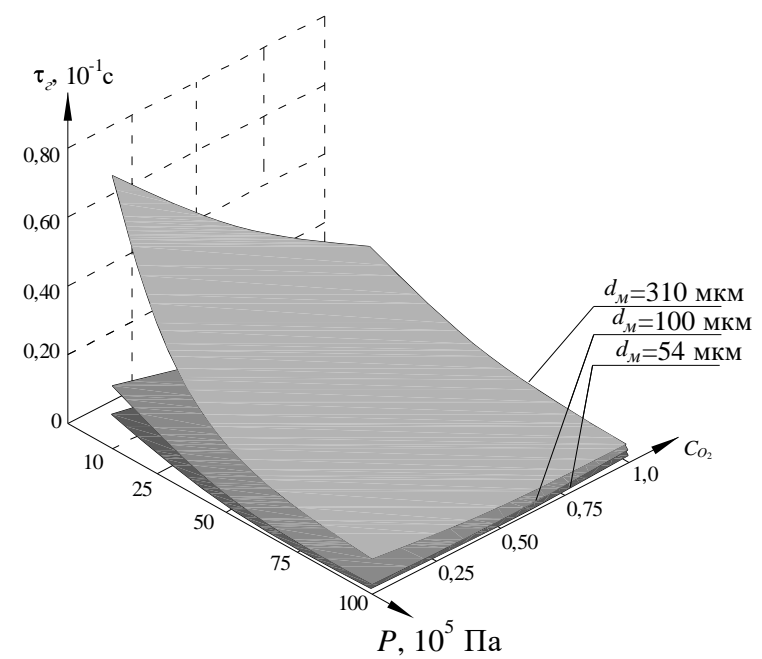

б)

Рисунок 8 - Тривимірне зображення залежностей часу згоряння частинки алюмінію у продуктах розкладання окиснювача: а) від $d_{m}$ та $\mathrm{C}_{02}$; б) від $\mathrm{C}_{02}$ та $P$

\section{Отримані}

експериментальностатистичні моделі (1), (2) надають можливість за допомогою стандартного програмного забезпечення в діалоговому режимі формувати керовану базу даних за температурами займання та часом згоряння частинок порошків магнію та алюмінію в газоподібних продуктах розкладання оксидів металів в умовах зовнішнього нагріву (рис. 5-8). Зазначений датасет може бути взятий за основу більш загальної керованої бази теоретико-
Джерело: розроблено (узагальнено авторами) експериментальних даних 3 визначення пожежонебезпечних властивостей піротехнічних виробів на основі сумішей, які розглядаються, в умовах зовнішніх термічних дій.

Висновки та напрями подальших досліджень. Встановлено нові закономірності комплексного впливу:

на температуру займання частинок магнію та алюмінію у продуктах розкладання оксидів металів таких параметрів: збільшення розміру частинок 
від $\mathrm{d}_{\mathrm{m}}=54$ мкм до $\mathrm{d}_{\mathrm{m}}=310$ мкм, відносного вмісту кисню від $\mathrm{C}_{\mathrm{O} 2}=0,2$ до $\mathrm{C}_{\mathrm{O} 2}=0,8$ та зменшення зовнішнього тиску від $P=3 \cdot 10^{7}$ Па до $P=10^{5}$ Па призводить до зменшення $T_{3}$ у $1,3 \ldots 1,8$ раза;

на час згоряння частинок магнію та алюмінію у продуктах розкладання оксидів металів таких параметрів: збільшення розміру частинок від $\mathrm{d}_{\mathrm{m}}=54$ мкм до $\mathrm{d}_{\mathrm{m}}=310$ мкм, зменшення відносного вмісту кисню від $\mathrm{C}_{\mathrm{O} 2}=0,8$ до $\mathrm{C}_{\mathrm{O} 2}=0,2$ та зовнішнього тиску від $P=3 \cdot 10^{7}$ Па до $P=10^{5}$ Па призводить до збільшення $\tau_{2}$ у $1,6 \ldots 3,7$ раза.

Розроблено нові експериментальностатистичні моделі, які дають змогу в режимі діалогу і реального часу проводити розрахунки на комп'ютері (відносна похибка $5 \ldots 7$ \%) рівнів температури займання й часу згоряння частинок магнію та алюмінію у продуктах термічного розкладання оксидів металів, що характеризують їх здатність до прискорення процесу горіння в умовах зовнішніх термодій (підвищені температури нагріву та тиски навколишнього середовища), формуючи базу даних щодо вибухонебезпечних режимів горіння сумішей за вказаних умов.

Враховуючи результати отриманих розрахунків та даних у подальшому планується проведення досліджень щодо вивчення пожежонебезпечних властивостей піротехнічних сумішей та створення відповідної бази даних щодо піротехнічних виробів.

\section{СПИСОК ВИКОРИСТАНИХ ДЖЕРЕЛ}

1. Шидловский А. А. Основы пиротехники. М. : Машиностроение, 1973. 320 с.

2. Металлические горючие гетерогенных конденсированных систем / Силин Н. А. и др. М. : Машиностроение, 1976.320 с.

3. Горение металлизированных гетерогенных конденсированных систем / Силин Н. А. и др. М. : Машиностроение, 1982. $232 \mathrm{c}$.

4. Процессы горения металлизированных конденсированных систем / Ващенко В. А. та ін. Київ : Наукова думка, 2008. 745 с.

5. Кириченко О. В. Повышение эффективности пиротехнических нитратосодержащих изделий в условиях их применения. Вісник Черкаського державного технологічного університету. 2009. № 2. С. 89-94.

6. Кириченко О. В., Пашковський П. С., Ващенко В. А., Лега Ю. Г. Основи пожежної безпеки піротехнічних нітратовмісних виробів в умовах зовнішніх термовпливів : монографія. Київ : Наукова думка, 2012. 318 с.

7. Fire safety improvement of pyrotechnic nitrate-metal mixtures under external thermal conditions / Dibrova O. and all. Technology audit and production reserves. 2020. № 1/1(51). Р. 44-49.

8. Вогман Л. П., Сотников О. В. Нормирование пожарной опасности фейерверочных пиротехнических изделий бытового назначения. Пожаровзрывобезопасность. 1998. № 2. С. 3-11.

9. ГОСТ Р 51270-2000. Изделия пиротехнические. Общие требования безопасности [Дата введения 2000-01-01]. М., 1999. $46 \mathrm{c.}$

10. Вогман Л. П., Зуйков Л. А., Татаров В. Е., Лепесий В. В. Разработка рекомендаций по обеспечению пожарной безопасности фейерверочных пиротехнических изделий. Пожаровзрывобезопасность. 2002. № 3. С. $24-41$.

11. ДСТУ 4105-2002. Вироби піротехнічні побутові. Загальні вимоги безпеки [Чинний від 2002-09-01]. Затверджено наказом Держстандарту України від 12. 06. 2002 р. № 356. Київ: Держстандарт України, 2002. 10 с.

12. Маковей В. А. Основные требования пожарной безопасности при обращении пиротехнической продукции. Чрезвычайные ситуации : промышленная и экологическая безопасность. 2011. № 1-3 (6-8). С. 13-21.

13. Ковалишин В. В., Марич В. М., Лозинський Р. Я. Проблеми гасіння магнію та його сплавів. Пожежна безпека. 2016. № 28. C. $58-63$.

14. Ковалишин В. В., Марич В. М. Проблеми гасіння магнію та його сплавів. Пожежна та техногенна безпека. Теорія, практика, інновації : матеріали міжнар. наук.-практ. конф., Львів (20-21 жовт. 2016 р.). Львів : ЛДУ БЖД, 2016. C. 304-305.

15. Filzen M. Feuerwehr-Essen: Feuer in Essener Hafenmühle, brennt gelagertes Aluminiumgranulat. Feuerwehr Essen. Pressemitteilung (vom 23.01.2016).

16. Tepper F., Kaledin L. Combustion characteristics of kerosene containing Alex nano- aluminum. Unsteady Combustion and Interior Ballistics: Lectures of the 3rd International Workshop. Saint Petersburg, 2000. P. 320-325.

17. Горение в воздухе смесей промышленных порошков алюминия со сверхтонкими порошками алюминия и оксида алюминия / Е. М. Попенко и др. Физика горения и взрыва. 2002. № 2. С. 36-41.

18. Федоров А. В., Харламова Ю. В. Воспламенение частицы алюминия. Физика горения и взрыва. 2003. Т. 39. № 5. С. $65-68$.

19. Калинчак В. В., Черненко А. С. Критические условия гетерогенного воспламенения нагретой частицы магния в холодном воздухе. Физика аэродисперсных систем. 2006. Вып. 43. С. 82-89.

20. Arkhipov V., Korotkikh A., Kuznetsov V. Ignition of energetic materials containing nanopowder of metals. Self-propagating Hightemperature Synthesis. Book of Proceedings of the IX International Symposium. Dijon, France, 2007. P. 43-44.

21. Кириченко О. В., Ващенко В. А., Акіньшин В. Д., Цибулін В. В. Спалахування частинок алюмінію в продуктах розкладання нітратовмісних окислювачів та органічних речовин піротехнічних сумішей при підвищених температурах 
нагріву. Пожежна безпека : теорія і практика. Збірник наукових праџзь. Черкаси : АПБ ім. Героїв Чорнобиля, 2011. № 9. C. $17-25$.

22. Кириченко О. В., Ващенко В. А., Цибулін В. В., Тупицький В. М. Керована база даних по часам згорання частинок металевих пальних в продуктах розкладання піротехнічних сумішей. Вісник Черкаського державного технологічного університету. 2012. № 4. С. 78-83.

23. Дослідження спалахування та горіння частинок алюмінієвомагніевих сплавів у продуктах розкладання твердих піротехнічних палив / Діброва О. С. та ін. Науковий вісник : Цивільний захист та пожежна безпека, 2019. № 2 (8). С. 8185.

24. Дослідження спалахування та горіння частинок металевого пального у продуктах розкладання нітратовмісних окиснювачів та органічних речовин при зовнішніх термічних впливах / Кириченко О. В. та ін. Сборник научных трудов : Проблемы пожарной безопасности, 2020. № 47. С. 50-59.

25. Виленкин С. Я. Статистическая обработка результатов исследования случайных величин. М. : Энергия, 1979. 320 с.

26. Корн Г., Корн Т. Справочник по математике для научных работников и инженеров. Определения, теоремы, формулы. М. : Наука, 1984. $831 \mathrm{c.}$

\section{REFERENCES}

1. Shidlovskiy A. (1973). Osnovy pirotekhniki [Fundamentals of pyrotechnics], Nauchnoye izdatel'stvo: Mashinostroyeniye. Moskow [in Russian].

2. Silin N., Vashchenko V., Kashporov L. (1976). Metallicheskiye goryuchiye geterogennykh kondensirovannykh sistem [Metallic combustible heterogeneous condensed systems]. Nauchnoye izdatel'stvo : Mashinostroyeniye. Moskow [in Russian].

3. Silin N., Vashchenko V., Kashporov L. (1982). Goreniye metallizirovannykh geterogennykh kondensirovannykh sistem [Combustion of metallized heterogeneous condensed systems]. Nauchnoye izdatel'stvo: Mashinostroyeniye. Moskow [in Russian].

4. Vashchenko V., Kirichenko O., Lega Yu., Zaika P., Yatsenko I., Tsybulin V. (2008). Protsessy goreniya metallizirovannykh kondensirovannykh sistem [Processes of combustion of metallized condensed systems], Naukova vidavnistvo : Naukova dumka. Kyiv [in Russian].

5. Kyrychenko O. (2009). Povyshenye éffektyvnosty pyrotekhnycheskykh nytratosoderzhashchykh yzdelyy v uslovyyakh ykh prymenenyya [Increasing the efficiency of pyrotechnic nitrate-containing products in terms of their application]. Naukovyy visnyk Cherkas'koho derzhavnoho tekhnolohichnoho universytetu. Cherkasy [in Russian].

6. Kyrychenko O., Pashkovs'kyy P., Vashchenko V., Leha Yu (2012). Osnovy pozhezhnoyi bezpeky pirotekhnichnykh nitratovmisnykh vyrobiv $\mathrm{v}$ umovakh zovnishnikh termovplyviv [Fundamentals of fire safety of pyrotechnic nitrate-containing products in the conditions of external thermal influences], Naukova vidavnistvo: Naukova dumka. Kyiv [in Russian].

7. Dibrova O., Kyrychenko O., Motrychuk R., Tomenko M., Melnyk V. (2020). Fire safety improvement of pyrotechnic nitrate-metal mixtures under external thermal conditions. Scientific Bulletin: Technology Audit and Production Reserves [in English].

8. Vogman L., Sotnikov O. (1998). Normirovaniye pozharnoy opasnosti feyyerverochnykh pirotekhnicheskikh izdeliy bytovogo naznacheniya [Rationing of fire hazard of fireworks pyrotechnic household products]. Pozharovzryvobezopasnost. Moskow [in Russian].

9. ГОСТ Р 51270-2000. Izdeliya pirotekhnicheskiye. Obshchiye trebovaniya bezopasnosti (1999) [Pyrotechnic products. General safety requirements]. M. $46 \mathrm{~s}$. [in Russian].

10. Vogman L., Zuikov V., Tatarov V., Lepesiy V. (2002). Normirovaniye pozharnoy opasnosti feyyerverochnykh pirotekhnicheskikh izdeliy bytovogo [Development of recommendations for ensuring fire safety of fireworks pyrotechnic products], Pozharovzryvobezopasnost [Fire and explosion safety]. Moskow [in Russian].

11. DSTU 4105-2002. Vyroby pirotekhnichni pobutovi. Zahalni vymohy bezpeky (2002). [Household pyrotechnic articles. General safety requirements]. [Chynnyi vid 2002-09-01]. Zatverdzheno nakazom Derzhstandartu Ukrainy vid 12. 06. 2002 r. № 356. Kyiv: Derzhstandart Ukrainy. 10 s. [in Ukrainian].

12. Makovey V. (2011). Osnovnyye trebovaniya pozharnoy bezopasnosti pri obrashchenii pirotekhnicheskoy produktsii [Basic requirements for fire safety when handling pyrotechnic]. Mezhdunarodnyy nauchno-prakticheskiy zhurnal : Chrezvychaynyye situatsii: promyshlennaya i ekologicheskaya bezopasnost. [in Russian].

13. Kovalishin V., Marich V., Lozynsky R. (2016). Problemy hasinnya mahniyu ta yoho splaviv [Problems of extinguishing magnesium and its alloys], Pozhezhna bezpeka [in Ukrainian].

14. Kovalishin V., Marich V. (2016). Problemy hasinnya mahniyu ta yoho splaviv [Problems of extinguishing magnesium and its alloys], Materialy Mizhnarodnoyi naukovo-praktychnoyi konferentsiyi: Teoriya, praktyka, innovatsiyi. Lviv [in Ukrainian].

15. Filzen M. (2016). Feuerwehr-Essen: Feuer in Essener Hafenmühle, brennt gelagertes Aluminiumgranulat. Feuerwehr Essen. Pressemit-teilung (vom 23.01.2016) [in German].

16. Tepper F., Kaledin L. (2000). Combustion characteristics of kerosene containing Alex nano- aluminum. Unsteady Combustion and Interior Ballistics: Lectures of the 3rd International Workshop [in English]

17. Popenko Ye., Il'in A., Gromov A., Kondratyuk S., Surgin V., Gromov A. (2002). Goreniye v vozdukhe smesey promyshlennykh poroshkov alyuminiya so sverkhtonkimi poroshkami alyuminiya i oksida alyuminiya [Combustion in air of mixtures of industrial aluminum powders with ultrafine powders of aluminum and aluminum oxide], Fizika goreniya $i$ vzryva. [in Russian].

18. Fedorov A., Kharlamova Yu (2003). Vosplameneniye chastitsy [Ignition of aluminum particles]. Fizika goreniya $i$ vzryva [in Russian].

19. Kalinchak V., Chernenko A. (2006). Kriticheskiye usloviya geterogennogo vosplameneniya nagretoy chastitsy magniya V kholodnom vozdukhe [Critical conditions for heterogeneous ignition of a heated magnesium particle in cold air]. Fizika aerodispersnykh sistem [in Russian].

20. Arkhipov V., Korotkikh A., Kuznetsov V. (2007). Ignition of energetic materials containing nanopowder of metals . Selfpropagating High-temperature Synthesis. Book of Proceedings of the IX International Symposium. Dijon, France, [in English].

21. Kyrychenko O., Vashchenko V., Akin'shyn V., Tsybulin V. (2011). Spalakhuvannya chastynok alyuminiyu V produktakh rozkladannya nitratovmisnykh okyslyuvachiv ta orhanichnykh rechovyn pirotekhnichnykh sumishey pry pidvyshchenykh temperaturakh nahrivu [Flame retardation of aluminum particles in the decomposition products of nitrate-containing oxidants and 
organic substances of pyrotechnic mixtures at elevated heating temperatures]. Zbirnyk naukovykh prats: Pozhezhna bezpeka: teoriya i praktyka. Cherkasy [in Ukrainian].

22. Kyrychenko O., Vashchenko Tsybulin V., Tupyts'kyy V. (2012). Povyshenye éffektyvnosty pyrotekhnycheskykh nytratosoderzhashchykh O. V.yzdelyy v uslovyyakh ykh prymenenyya [Increasing the efficiency of pyrotechnic nitrate-containing products in terms of their application]. Naukovyy visnyk Cherkas'koho derzhavnoho tekhnolohichnoho universytetu. Cherkasy [in Ukrainian].

23. Kyrychenko O., Dibrova O., Motrichuk R., Vashchenko V., Kolin'ko S. (2019). Doslidzhennya spalakhuvannya ta horinnya chastynok alyuminiyevomahnievykh splaviv u produktakh rozkladannya tverdykh pirotekhnichnykh palyv [Research of ignition and combustion of particles of aluminum-magnesium alloys in decomposition products of solid pyrotechnic fuels]. Naukovyy visnyk: Tsyvil'nyy zakhyst ta pozhezhna bezpeka. [in Ukrainian].

24. Kirichenko O., Motrichuk R., Dibrova O., Melnyk V., Vashchenko V., Butenko T. (2020). Doslidzhennya spalakhuvannya ta horinnya chastynok metalevoho pal'noho u produktakh rozkladannya nitratovmisnykh okysnyuvachiv ta orhanichnykh rechovyn pry zovnishnikh termichnykh vplyvakh [Research of ignition and combustion of metallic fuel particles in decomposition products of nitrate-containing oxidants and organic substances under external thermal influences]. Sbornyk nauchnykh trudov : Problemy pozharnoy bezopasnosty [in Ukrainian].

25. Vilenkin S. (1979). Statisticheskaya obrabotka rezul'tatov issledovaniya sluchaynykh velichin [Statistical processing of the results of the study of random variables]. Nauchnoye izdatel'stvo: Energiya [in Russian].

26. Korn G., Korn T. (1984). Spravochnik po matematike dlya nauchnykh rabotnikov i inzhenerov. Opredeleniya, teoremy, formuly [Handbook of Mathematics for Scientists and Engineers. Definitions, theorems, formulas]. Nauchnoye izdatel'stvo : Nauka [in Russian]. 
Науковий вісник : Цивільний захист та пожежна безпека № 2 (12) 2021

\title{
REGULARITIES OF INFLUENCE OF TECHNOLOGICAL PARAMETERS AND EXTERNAL FACTORS ON THE IGNITION TEMPERATURE AND COMBUSTION TIME OF MAGNESIUM AND ALUMINUM IN DECOMPOSITION PRODUCTS OF METAL OXIDES
}

\author{
Ye. Kyrychenko, V. Gvozd, V. Vaschenko, O. Kyrychenko, O. Diadiushenko, V. Melnyk
}

Cherkasy Institute of Fire Safety named after Chernobyl Heroes National University of Civil Defence of Ukraine

\begin{tabular}{l} 
KEYWORDS \\
\hline pyrotechnic metal- \\
containing \\
mixtures, fire \\
safety, processes \\
of ignition and \\
combustion of \\
metal particles.
\end{tabular}

metal particles.

\begin{abstract}
ANNOTATION
Areas of application of pyrotechnic mixtures in various branches of economic activity and the main sources of their danger during fires and emergencies in their places of storage are analyzed. Experimental researches are carried out and experimental-statistical models of complex influence on ignition temperature and burning time of magnesium and aluminum particles in decomposition products of metal oxides of the following parameters are developed: dispersion of metal fuel, relative oxygen content, external pressure. New experimental and statistical models have been developed, which allow to calculate the levels of ignition temperature and combustion time of magnesium and aluminum particles in the products of thermal decomposition of metal oxides in the mode of dialogue and real time, forming a database on explosive combustion modes of mixtures. Experimental and statistical models allow to form a controlled database of ignition temperatures and combustion times of magnesium and aluminum powder particles in gaseous decomposition products of metal oxides under external heating. The developed database is convenient for assessing the fire-hazardous properties of pyrotechnic articles based on pyrotechnic mixtures, the main parameters of which are elevated heating temperatures and external pressures and can be used as a basis for a more general managed database of theoretical and experimental data to determine fire-hazardous properties of pyrotechnic articles. in the conditions of external thermal actions.

The obtained results will be the basis for the organization and conduct of research on the fire-hazardous properties of pyrotechnic mixtures and the creation of a modern database of products and products for pyrotechnic purposes.
\end{abstract}

